\title{
Imposed separation of conjoined twins- moral hubris by the English courts?
}

Raanan Gillon Imperial College of Science, Technology and Medicine, London University

Late last year the English Court of Appeal confirmed a lower court's ruling that doctors could impose an operation to separate recently born conjoined twins, overriding the refusal of consent of their parents. The doctors believed the operation would probably save one of the babies at the cost of killing the other, while not operating would highly probably be followed by the death of both twins within months of their birth. The parents, said to be devout Roman Catholics, believed that it was absolutely wrong to kill one of their babies, even to save the life of the other.

Undoubtedly many people, the writer included, would agree with the English courts that the "least worst" option was to separate the twins and save one at the cost of killing the other. But surely many fewer people would have imposed their own resolution of this acute moral dilemma upon parents who conscientiously chose the other limb of the dilemma, refusing to kill one baby even in order to save the other. Were the English judges right, then, to take away the parents' normal right and duty to make health care decisions on behalf of their children and instead impose their own answer to what they admitted to be a terrible dilemma? Describing the two alternatives in terms of choosing between the lesser of two evils on the one hand, and the obligation not to kill on the other, Lord Justice Ward declared, according to The Times law report, ${ }^{1}$ that: "Parents who were placed on the horns of such a terrible dilemma simply had to choose the lesser of their inevitable loss [ sic]". But that surely is to beg the moral question in favour of the judges' preferred answer to this moral dilemma. The fact is that there are-as is characteristic of all moral dilemmas - strong moral reasons for coming to two moral conclusions that are mutually inconsistent, at least in the sense that both cannot be achieved and sometimes in the sense, as here, that they are mutually contradictory. Thus there are strong moral reasons for not killing one baby to save the other even at the cost of the tragedy that both will die; and there are strong moral reasons for saving one baby's life rather than allowing both to die, even at the cost of the tragedy that one will be deliberately killed.

Neither of these alternative positions are eccentric, peculiar to a small group or sect of believers, and rejected by society as permissible justifications for parents to deny life-saving interventions to their children. Christian Scientists, for example, or Jehovah's Witnesses, while they, like all competent adults, may refuse life-prolonging medical interventions for themselves on the basis of their beliefs, including their religious beliefs, are not permitted to impose those beliefs upon their children when to do so severely threatens those children's welfare. Why then, it might be asked, should the parents of these conjoined twins be treated differently? Were not their religious views threatening the life of one of their babies?

That certainly seems to have been the reasoning of the English courts. Meticulously considering the interests of each child if the operation were carried out or not, the judges concurred that while it was in the best interests of Mary, the weaker twin, not to be killed by the operation, it was also in the best interests of Jody, the stronger twin, that the operation should be carried out. In such a conflict of interests "there was no other way of dealing with it than by choosing the lesser of the two evils and so finding the least detrimental alternative". ${ }^{1}$ But this assertion simply affirms one limb of the moral dilemma, ignores the other, and begs the moral question as to which is "the lesser of the two evils". For there is another way of dealing with the dilemma, notably the parents' way, which is to reason that not killing an innocent baby is the lesser of the two evils, since it is absolutely morally prohibited, even if the baby would in any case die in a matter of months and even if such killing saved the other baby's life.

This alternative way of dealing with the moral dilemma does not result from an eccentric religious position held only by a small group or sect; on the contrary it results from a standard line of moral reasoning common not only to Roman Catholicism but to many, probably most, societies, both secular and religious. In its most obviously relevant form it forbids (under English law, for example) the killing of one innocent infant, even if already dying, to save another. Consider the following thought experiment. Two identical twins are born. One will incurably die within a few months, but has healthy lungs and a healthy heart. The other has a feeble heart and poor lungs, and will also soon die unless she is 
given a compatible heart lung transplant in which case she is likely to survive. Only her identical twin's heart and lungs are compatible with her own tissue type, and in any case no other transplant donor is available in the time left before she will die. Either an early heart lung transplant is carried out using her identical twin sister as "donor" which would kill her-but she was going to die soon anyway- or both twins will die, one of whom could have been saved by killing the other. Imagine the outrage of the English Court of Appeal, if a lower court had judged that in such a case, though the best interests of the incurably dying twin precluded being killed prematurely in order to provide a life-saving heart lung transplant for her sister, none the less the best interests of the other twin were to obtain such a transplant, and since without medical intervention both children would die, whilst with intervention using the twin as donor at least one child would be saved, "there was no other way of dealing with it than by choosing the lesser of the two evils and so finding the least detrimental alternative". Although Lord Justice Ward (perhaps anticipating such a thought experiment?) explicitly stated that the Court of Appeal's judgment would not be authority for a doctor to kill a patient once the doctor had determined that the patient could not survive, it is difficult to see why such an extension of reasoning, based on comparing children's competing interests, should not apply to separate children as much as it applies to conjoined children. ${ }^{2}$

One way to escape the comparison is to argue that in the case of the conjoined infants the child who was killed was not, as in the thought experiment, providing a heart and lungs to the other but rather ceasing to "suck the life blood out" of the other (as Lord Justice Ward vividly - and probably to many offensively - put it), ceasing to be an uninvited parasite, as again Lord Justice Ward put it, upon the heart and lungs of her sister. Certainly that is one way of breaking the analogy, and it has resonances with Judith Jarvis Thomson's "famous violinist" argument. ${ }^{3}$ Jody never asked for Mary to be attached to her heart and lungs and should be allowed to be disconnected from her "blood sucking", "parasite", sister, who was not only compromising her bodily integrity and human dignity, but was shortly going to kill her. On this basis Mary was to be seen as an (unintentional) aggressor whom it was justifiable for Jody or her proxies, if necessary, to kill in defence of Jody. If that was the reasoning the judges ought to have spelt it out, but of course it is by no means clear cut or uncontentious an argument.

The alternative interpretation is that the twins were born essentially sharing one set of heart and lungs, because of the failure of normal development, and that there was no good reason- only a morally irrelevant locational explanation - to argue that the heart and lungs belonged to Jody rather than to Mary; rather they should be seen as belonging to both. But even if this interpretation is rejected, the parallel between the thought experiment and the twins' case still holds in one (literally) vital respect: in each case one twin has to be deliberately killed if the other is to be saved. It is surely morally mistaken - or else morally hubristic - to assume that "choosing the lesser of the two evils" morally entails killing one child in order to save the other, where otherwise both will die; for the alternative "lesser of two evils" is to allow both to die - as in the common rejection of killing that the thought experiment makes clear-rather than deliberately to kill one child in order to save another.

Given these two powerful lines of moral reasoning-one absolutist consequentialist, one absolutist deontological - each leading to mutually incompatible tragic moral conclusions, ie given this tragic moral dilemma, what should the judges have done ?

It seems to this writer morally far preferable for the court, having spelled out the moral dilemma, to have ruled that there was no legal obligation - and perhaps no legal justification-in this case for removing the normal responsibility and right of parents to make health care decisions for their children. The parents were neither incompetent nor negligent - the standard justifications for depriving parents of such authority-and their reasoning was not eccentric or merely religious, but was widely acceptable moral reasoning - as was the contrary moral reasoning justifying an operation. The court should thus have declined to deprive the parents of their normal responsibilities and rights in order to impose its own preferred resolution of the moral dilemma, and should have allowed the parents to refuse medical intervention-while still ruling as it did, that such separation would not have been unlawful had the parents consented.

\section{(See Ethics briefings, page 62.)}

\section{References and notes}

1 Times law report. Resolving conflict of babies' interests. In re A (Minors) (Conjoined twins: medical treatment). The Times (Times 2 law report). 2000 Oct 10:27. Full transcript at: wwwcourtservice.gov.uk

2 Since writing this editorial my attention has been drawn, in a discussion with Dr Louis Reynolds of the University of Cape Town, to a similar hypothetical example in a paper by S Sheldon and S Wilkinson, Conjoined twins: the legality and ethics of sacrifice. Medical Law Review 1997;5:149-71. Although I had not read their paper I would like to acknowledge their priority and to thank Dr Reynolds.

3 Thomson J. A defense of abortion. Philosophy and Public Affairs 1971;1:47-66. 